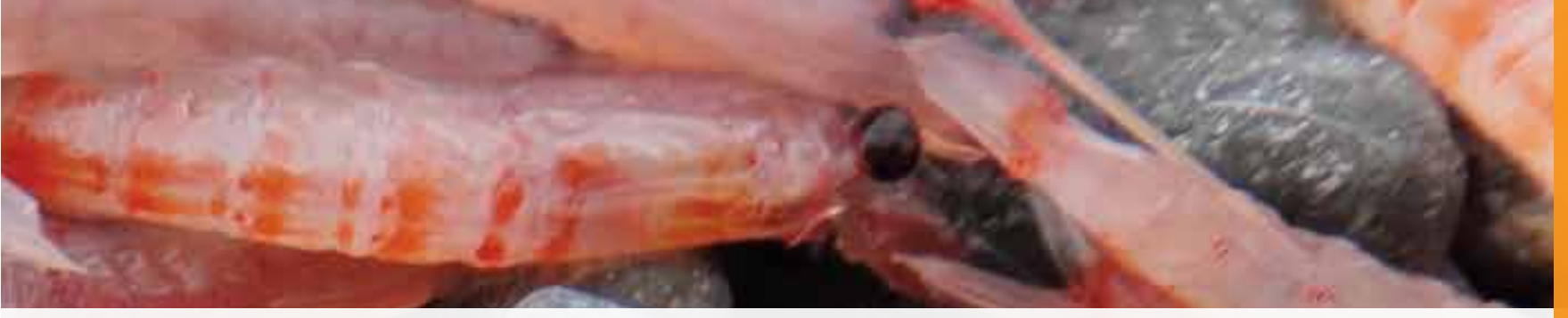

\title{
CHLOROPHYLL a BIOMASS AND ACCESSORY CHLOROPHYLL PIGMENTS IN THE SHALLOW COASTAL ZONE AT ADMIRALTY BAY, ANTARCTICA: COMPARISON BETWEEN TWO CONSECUTIVE AUSTRAL SUMMERS
}

\author{
Márcio Murilo Barboza Tenório ${ }^{1 *}$, Fernanda de Alcântara Vaz Pinto1, \\ José Juan Barrera-Alba ${ }^{1,{ }^{* \star}}$, Jacques Neveux ${ }^{3 \star \star *}$ \& Denise Rivera Tenenbaum ${ }^{1 *}$ \\ 'Laboratório de Fitoplâncton Marinho, Instituto de Biologia, Universidade Federal do Rio de Janeiro - UFRJ, Av. Carlos Chagas Filho, \\ 373, CCS, sala A-61, Ilha do Fundão, Cidade Universitária, CEP 21949-902, Rio de Janeiro - RJ, Brasil \\ 2Departamento de Ciências do Mar, Campus Baixada Santista, Universidade Federal de São Paulo - UFRJ, Av. Saldanha da Gama, 89, \\ Ponta da Praia, CEP 11030-400, Santos - SP, Brasil \\ ${ }^{3}$ UMR 7621, LOMIC - CNRS, Université Pierre et Marie Curie, Laboratoire Arago, 66650 Banyuls-sur-mer, France \\ e-mails: *marcio.tenorio@biologia.ufrj.br, **juanalba@biologia.uffi.br,***neveux.jacques@orange.fr, \#deniser@biologia.ufrj.br
}

\begin{abstract}
Chlorophyll a and accessory chlorophyll concentrations of the phytoplankton community were studied in Admiralty Bay in early and late summer of 2009/2010 and 2010/2011, using spectrofluorometry. Chlorophyll a biomass increased from early to late summer and was higher in 2010/2011 than in 2009/2010. The ratios of accessory pigments to Chlorophyll a showed a greater presence of chlorophytes relative to chromophytes in 2009/2010 than in 2010/2011 summer. The variations observed in chlorophyll biomass and accessory pigments to Chlorophyll a ratios was associated to increase in water temperature during austral summer.
\end{abstract}

Keywords: Chlorophylls, Spectrofluorometry, Western Antarctic Peninsula, Admiralty Bay

\section{Introduction}

The chlorophyll $a(\mathrm{Chl} a)$ concentration is one of the most measured oceanographic variables to determine phytoplankton biomass and primary production in waters. Although $\mathrm{C} / \mathrm{Chl}$ a ratio shows important variations according to environmental changes, $\mathrm{Chl} a$ remains the best proxy of phytoplankton biomass for studying spatial and temporal variability of primary productivity (Huot et al., 2007). Associated with Chl $a$ in more specific phytoplankton taxa, accessory pigments (like chlorophyll $b$ and chlorophyll $c$, amongst others) provides useful information concerning taxonomic composition, photoadaptability and the physiological status of the algal community (Neveux \& De Billy, 1986). However, there is still no information about these variables in Admiralty Bay, King George Island.

The Chl $a$ biomass is generally low in the Southern Ocean despite the presence of high macronutrient concentration (Martin et al., 1991; Rose et al., 2009). Research studies in Admiralty Bay since the 80's reported $\mathrm{Chl} a$ concentrations during summer periods usually below $1 \mu \mathrm{g} \mathrm{L}^{-1}$ (Kopczynska, 1980; Lipski, 1987; Lange et al., 2007). Phytoplankton biomass in Antarctic Waters shows high variability at different time scales (weekly to interannual) that is driven by physical, chemical and biological forcing like water column stabilization which is affected by local wind stress, temperature, nutrients, light availability, grazing pressure, dynamics related to sea ice melt and glacial melt water, among others (Moline \& Prézelin, 1996; Smith et al., 2008).

In this study we present the temporal and spatial variability of chlorophylls concentration in Admiralty Bay, King George Island, during 2009/2010 and 2010/2011 summers. 


\section{Materials and methods}

\section{Study area and sampling}

Admiralty Bay $\left(62^{\circ} 03^{\prime}-12^{\prime} \mathrm{S}, 58^{\circ} 18^{\prime}-38^{\prime} \mathrm{W}\right)$, located at King George Island, has been the focus of a Brazilian National Monitoring Program from the National Institute of Science and Technology - Antarctic Environmental Research (INCTAPA) since 2008. The sampling methodology follows the standard procedures for hydrological (Cascaes et al., 2012) and plankton studies (Tenório et al., 2011; Tenenbaum et al., 2011). Measurements of Chl $a$ were obtained from surface, $15 \mathrm{~m}$ and near the bottom $(\approx 29 \mathrm{~m})$ at five stations in early (ES) and late (LS) summers (2009/2010 and 2010/2011) during 12 surveys from Antarctic Operations (AO) XXIX and XXIX ( $\mathrm{n}=180$ samples). Temperature was measured in situ with a Seamon Mini sensor. Salinity and nutrients chemical analyses was presented on Cascaes et al. (2012).
Spearman's rank correlation coefficient (r) was used to measure the degree of association between pigments and physical and chemical variables.

\section{Chlorophyll pigments}

Water filtration, sample storage and extraction of chlorophyll pigments were described in Tenório et al. (2011). Fluorescence properties of the acetonic extracts were measured on a Varian Cary Eclipse spectrofluorometer. Concentrations of $\mathrm{Chl} a, b$ and $c$ were assessed using a modified version of Neveux \& Lantoine's (1993) method as described by Tenório et al. (2005). The significance of spectrofluorometric results is related both to the relative concentrations of the pigment in the extracts and to its quantum yield in the solvent used. Only an accessory chlorophyll concentration which represented at least 5\% (weight to weight) of $\mathrm{Chl} a$ will be considered significant.

Table 1. Physical, chemical and biological variables at Admiralty Bay during the $2009 / 2010$ and $2010 / 2011$ surveys. Pigment ratios are weight to weight ratios.

\begin{tabular}{|c|c|c|c|c|c|c|c|c|}
\hline Surveys & Periods & & $\begin{array}{c}\text { Temperature } \\
\left({ }^{\circ} \mathrm{C}\right)\end{array}$ & Salinity & $\begin{array}{c}\text { Chl a } \\
\left(\mu \mathrm{g} \mathrm{L}^{-1}\right)\end{array}$ & $\begin{array}{c}\text { Chl a } \\
\left(\mathbf{m g ~ m}^{-2}\right)\end{array}$ & Chl $b / \mathbf{C h l} a$ & Chl $c / \mathbf{C h l} a$ \\
\hline \multirow[t]{10}{*}{ 2009/2010 } & \multirow{5}{*}{$\begin{array}{l}\text { Early } \\
\text { Summer }\end{array}$} & Min & -0.63 & 33.77 & 0.13 & 4.36 & 0.07 & 0.11 \\
\hline & & Max & 1.16 & 34.43 & 0.67 & 17.70 & 0.19 & 0.20 \\
\hline & & Av & 0.06 & 34.16 & 0.34 & 10.07 & 0.12 & 0.15 \\
\hline & & SD & 0.40 & 0.14 & 0.11 & 3.24 & 0.03 & 0.02 \\
\hline & & $n$ & 60 & 60 & 60 & 60 & 60 & 60 \\
\hline & \multirow{5}{*}{$\begin{array}{l}\text { Late } \\
\text { Summer }\end{array}$} & Min & 0.38 & 33.64 & 0.15 & 6.09 & 0.04 & 0.13 \\
\hline & & Max & 1.35 & 34.30 & 0.92 & 24.50 & 0.12 & 0.26 \\
\hline & & Av & 0.82 & 34.09 & 0.48 & 14.05 & 0.08 & 0.18 \\
\hline & & SD & 0.23 & 0.17 & 0.24 & 6.81 & 0.02 & 0.03 \\
\hline & & $n$ & 45 & 45 & 45 & 45 & 45 & 45 \\
\hline \multirow[t]{10}{*}{$2010 / 2011$} & \multirow{5}{*}{$\begin{array}{l}\text { Early } \\
\text { Summer }\end{array}$} & Min & 0.13 & 33.38 & 0.36 & 12.98 & 0.02 & 0.11 \\
\hline & & Max & 1.49 & 34.87 & 3.72 & 45.27 & 0.10 & 0.18 \\
\hline & & Av & 0.62 & 34.18 & 0.84 & 24.60 & 0.05 & 0.15 \\
\hline & & SD & 0.28 & 0.23 & 0.51 & 8.81 & 0.02 & 0.01 \\
\hline & & $n$ & 45 & 45 & 45 & 45 & 45 & 45 \\
\hline & \multirow{5}{*}{$\begin{array}{l}\text { Late } \\
\text { Summer }\end{array}$} & Min & 1.39 & 33.4 & 0.40 & 23.05 & 0.04 & 0.16 \\
\hline & & Max & 1.92 & 34.31 & 6.11 & 166.56 & 0.11 & 0.19 \\
\hline & & Av & 1.62 & 34.12 & 2.84 & 82.23 & 0.05 & 0.18 \\
\hline & & SD & 0.14 & 0.21 & 1.73 & 48.65 & 0.02 & 0.01 \\
\hline & & $n$ & 30 & 30 & 30 & 30 & 30 & 30 \\
\hline
\end{tabular}

minimum (Min), maximum (Max), average (Av) , standard deviation (SD) , sample numbers (n) 
This does not mean necessarily that $\mathrm{Chl} b$ or $\mathrm{Chl} c$ are absent, but that the accuracy of its determination is poor below this threshold (Neveux et al., 2009).

\section{Results}

Due to the spatial and vertical homogeneity of thermohaline structure in shallow waters of Admiralty Bay, the environment variables and chlorophyll pigments concentrations are averaged $(n=15)$ for each survey (Figures 1 and 2).

The results showed a gradual increase of temperature in Admiralty Bay waters from the beginning of summer through its end (Figure 1a, Table 1). Moreover, a strong interannual thermal variation of averaged temperature was observed with values 2.5 times lower during the 2009/2010 summer $\left(0.40 \pm 0.47{ }^{\circ} \mathrm{C}\right)$ than during the $2010 / 2011$ summer $\left(1.02 \pm 0.54{ }^{\circ} \mathrm{C}\right)$. The haline structure exhibited slight temporal variations (Figure 1, Table 1), and similar averaged values for both summers 2009/2010 (34.13 \pm 0.15$)$ and 2010/2011 (34.16 \pm 0.23$)$.

\section{Chlorophyll a, an indicator of overall phytoplankton abundance}

During 2009/2010 Chl a concentration was low $\left(0.48 \pm 0.24 \mu \mathrm{g} \mathrm{L}^{-1}\right)$ showing values lower than $0.5 \mu \mathrm{g} \mathrm{L} \mathrm{L}^{-1}$ in $93 \%$ of the samples during ES and 53\% in LS. Integrated Chl $a$ $(0-29 \mathrm{~m})$ increased $\sim 28 \%$ from early $\left(10.07 \pm 3.24 \mathrm{mg} \mathrm{m}^{-2}\right)$ to late summer $\left(14.05 \pm 6.81 \mathrm{mg} \mathrm{m}^{-2}\right)$ (Figure 2a; Table 1).
Temperature $(\mathrm{r}=0.51 ; p=0.001)$ and $\mathrm{SiO}_{4}$ concentrations ( $\mathrm{r}=-0.38 ; p=0.02$ ) were the variables that seemed to have an influence on chlorophyll biomass variation. In 2010/2011, Chl $a$ values were lower than $1 \mu \mathrm{g} \mathrm{L}^{-1}$ in $58 \%$ of the samples during ES and only 16\% during LS. In 2009/2010, integrated Chl $a$ also increased but with an higher amplitude, approximately three times from ES to LS $\left(24.60 \pm 8.81 \mathrm{mg} \mathrm{m}^{-2}\right.$ to $\left.82.23 \pm 48.65 \mathrm{mg} \mathrm{m}^{-2}\right)$, and were six times higher than during 2009/2010 (Figure 2a; Table 1). Similarly to that observed in the previous survey Chl $a$ variations were influenced by water temperature $(r=0.86$; $p<0.001)$ and $\mathrm{SiO}_{4}(\mathrm{r}=-0.53 ; p=0.003)$. However, in this case, $\mathrm{NO}_{3}$ concentrations also showed a significant influence $(\mathrm{r}=-0.47 ; p=0.01)$.

\section{Accessory chlorophylls ratio: relative indices of eukaryotic components of phytoplankton communities.}

During 2009/2010, the $\mathrm{Chl} b / \mathrm{Chl} a$ ratio (Figure 2b; Table 1$)$ decreased from ES $(0.12 \pm 0.03)$ to LS $(0.08 \pm 0.02)$. However, in the last sampling of LS, the ratio increased to an intermediate level between the last two ES samplings (Figure 2b; Table 1). On the other hand, $\mathrm{Chl} c / \mathrm{Chl} a$ ratio increased from $0.15 \pm 0.02$ (ES) to $0.18 \pm 0.03$ (LS). This ratio was higher than $\mathrm{Chl} b / \mathrm{Chl} a$, except at the beginning of the sampling period. The two ratios showed a significant negative correlation $(\mathrm{r}=-0.43 ; p=0.007)$. The $\mathrm{Chl} c / \mathrm{Chl} a$ ratio was positively correlated with $\mathrm{Chl} a(\mathrm{r}=0.51 ; p=0.001)$
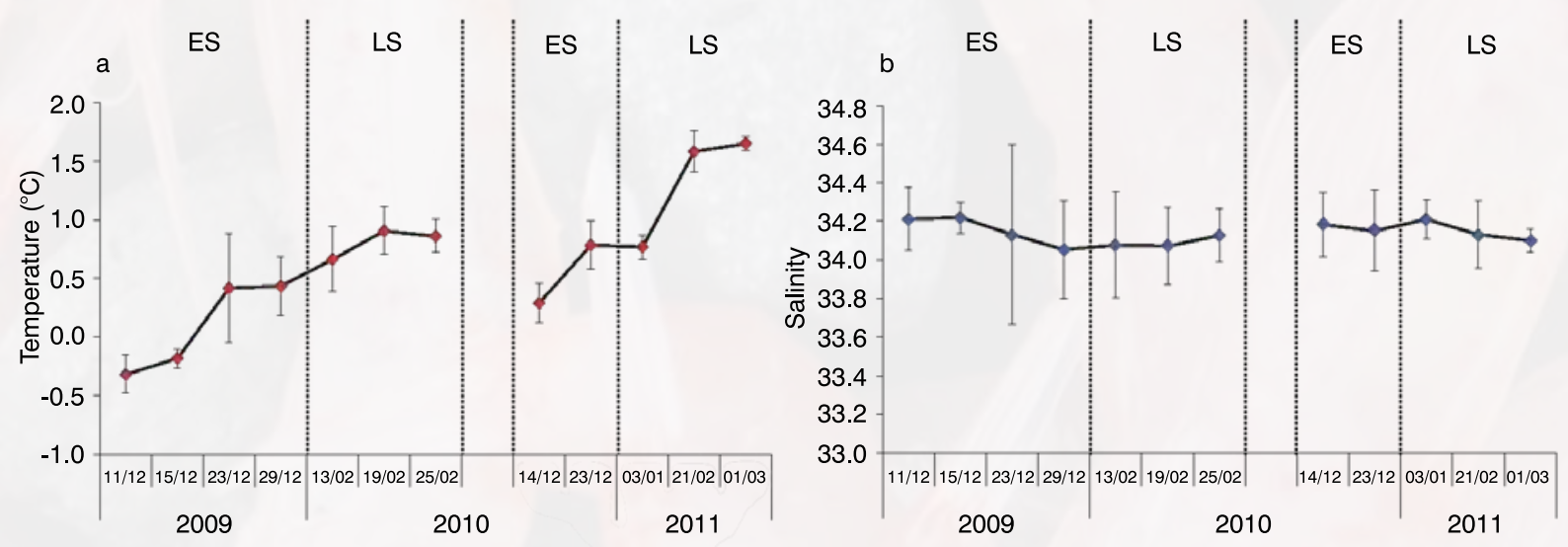

Figure 1. Temporal variation of water temperature (a) and salinity (b) in Admiralty Bay during 2009/2010 and 2010/2011 surveys. ES - Early Summer, LS Late Summer. 
showing that $\mathrm{Chl} a$ concentrations were rather associated to chromophytes. The variations of the $\mathrm{Chl} c / \mathrm{Chl} a$ ratio seems to be influenced by temperature $(\mathrm{r}=0.60 ; p<0.001)$ and $\mathrm{SiO}_{4}$ concentrations $(\mathrm{r}=-0.48 ; p=0.03)$ and suggests variations of the relative importance of diatoms in the communities. The Chl $b / \mathrm{Chl} a$ ratio was negatively correlated to water temperature $(\mathrm{r}=-0.76 ; p<0.001)$, suggesting a relative preference of chlorophytes for colder waters.

In the summer 2010/2011 Chl $b$ concentrations were low and significant values were not observed in $60 \%$ of the samples (Figure $2 \mathrm{~b}$ ). Chl $b$ content was found in significant quantities in the last ES sampling (Chl $b / \mathrm{Chl} a=0.06$ ), and at the LS start (Chl $b / \mathrm{Chl} a=0.05)$ (Figure 2b). The Chl $b /$ Chl $a$ ratio was clearly lower in 2010/2011 than in 2009/2010 (Figure 2a; Table 1). The Chl c/Chl $a$ ratio was at similar levels compared to 2009/2010. It was positively correlated with integrated $\mathrm{Chl} a$ concentrations ( $\mathrm{r}=0.57$; $p=0.001$ ) showing the importance of Chromophytes in chlorophyll biomass. Furthermore, water temperature $(\mathrm{r}=0.60 ; p<0.001)$ and $\mathrm{SiO}_{4}$ concentrations $(\mathrm{r}=-0.48$; $p=0.004$ ) also seemed to influence the variation of this group during this summer.

\section{Discussion}

Temporal variation of thermohaline structure was similar to those reported in previous studies (Lipski, 1987; Lange et al., 2007). However, water temperatures recorded on December 2009 were lower to those usually reported, probably due to the influence of El Niño (National Oceanic and Atmospheric Administration - NOAA, EUA). In general, Chl $a$ concentrations were low (1- $2 \mu \mathrm{g}$ L-1) in spite of high dissolved inorganic nutrients concentrations (Cascaes et al., 2012), as commonly reported in Admiralty Bay (Lipski, 1987; Lange et al., 2007; Kopczynska, 2008). One of the explanations for this paradox is usually associated to the low micronutrient iron availability, which is considered as one of the main factors limiting phytoplankton growth under high macronutrients conditions (Martin et al., 1991; Rose et al., 2009). Studies developed on Antarctic phytoplankton cultures showed that both iron addition and increase in water temperature, lead to rise of chlorophyll biomass (Rose et al., 2009). In this way, the increase of biomass in LS was mainly conditioned by rise of temperature, which melts the ice providing the micronutrient iron to phytoplankton growth (Martin et al., 1991). So, the low water temperatures observed during the 2009/2010 atypical summer (three times lower than summer 2010/2011) could explain the Chl $a$ concentrations six times lower than during the 2010/2011 summer.

The relatively high $\mathrm{Chl} b / \mathrm{Chl} a$ ratio $(0.10 \pm 0.03)$ in $2009 / 2010$ survey pointed out a higher contribution of $\mathrm{Chl} b$-containing classes of the green algal lineage associated to low water temperatures $\left(0.40 \pm 0.48^{\circ} \mathrm{C}\right)$. At much higher water temperatures $\left(1.10 \pm 0.56^{\circ} \mathrm{C}\right)$, as observed during $2010 / 2011$ summer, the pigment ratios were lower $(<0.05)$. These results were coherent with those of Hashihama et al. (2008), showing higher densities of chlorophytes associated to colder waters in the Antarctic marginal ice zone along

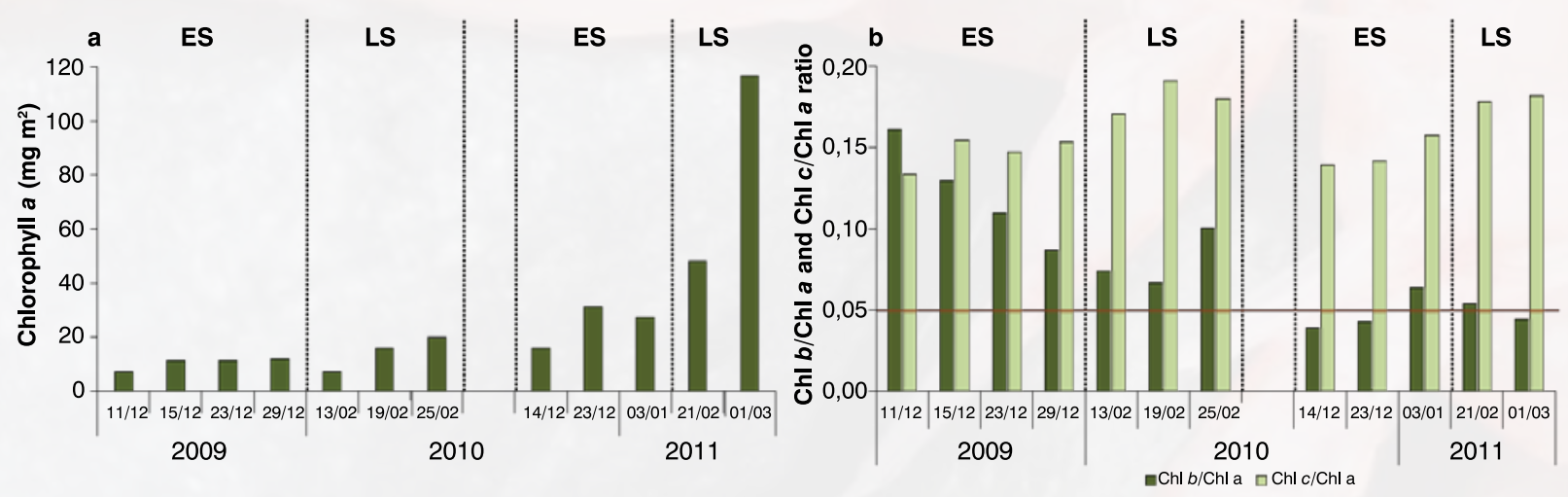

Figure 2. Temporal variation of Chlorophyll pigments: a) Chl a concentration, b) Chl b/ Chl a and Chl c/Chl a ratio in Admiralty Bay during $2009 / 2010$ and 2010/2011 surveys. ES - Early Summer, LS - Late Summer. Red line represents thresholds for significant values of Chl b and Chl $c$. 
the $140^{\circ} \mathrm{E}$ meridian. Relatively high $\mathrm{Chl} c / \mathrm{Chl} a$ during 2009/2010 survey could be related to elevated densities of cryptophytes single-celled flagellated algae lower than $10 \mu \mathrm{m}$ (Moline et al., 2004), identified at the same period in an adjacent region through HPLC analysis (Mendes et al., 2013). In this sense, the dominance of phytoplankton $<10 \mu \mathrm{m}$, which represented $\sim 80 \%$ of biomass in this survey, had already been highlighted by Tenório et al. (2011). Besides cryptophytes, other chromophytes, like microplanktonic dinoflagellates and diatoms present in Admiralty Bay (Tenenbaum et al., 2011), also contributed to the increase of Chl c/Chl $a$ ratios during 2009/2010 summer.

\section{Conclusion}

Temporal variation in water temperature, chlorophyll biomass and accessory chlorophyll/chlorophyll $a$ ratios show important interannual variations. The increase in water temperature during the austral summer lead to enhance of chlorophyll biomass and to variation of accessory pigments to $\mathrm{Chl} a$ ratios, showing significant changes in the phytoplankton community structure. Nevertheless, similar Chl $c / \mathrm{Chl} a$ ratio between summers and higher Chl $b /$ Chl $a$ in 2009/2010 possibly suggests: 1) higher contribution of other taxonomic groups on chlorophyll biomass (e.g. cyanobacteria) instead of chlorophytes in the second survey 2) reduction in Chl $c$ per cell during 2010/2011 summer due to variations in the composition of chromophytes or/and light availability.

Pigment concentrations studies in the Admiralty Bay proved to be a good tool for monitoring the effects of global changes both on phytoplankton biomass and on the relative proportions of chlorophyll $b$ (chlorophytes) and chlorophyll $c$ (chromophytes) containing eukaryotes.

\section{Acknowledgments}

This work integrates the National Institute of Science and Technology Antarctic Environmental Research (INCT-APA) that receive scientific and financial supports of the National Council for Research and Development (CNPq process: $\mathrm{n}^{\circ}$ 574018/2008-5) and Research Support Foundation of the State of Rio de Janeiro (FAPERJ $n^{\circ}$ E-16/170.023/2008). The authors also acknowledge the support of the Brazilian Ministries of Science, Technology and Innovation (MCTI), of Environment (MMA) and Inter-Ministry Commission for Sea Resources (CIRM) and Marine Organic Chemical Laboratory of the Oceanographic Institute of São Paulo University (LabQOM-IOUSP). M. M. B. Tenório thanks FAPERJ/CAPES for the post-doctoral fellowship under process no E-26/102.015/2009.

\section{References}

Cascaes, M. J., Barbosa, A. C. R. A., Freitas, F. S., Calabuano, F. I., Silva, J., Patire, V. F. et al. (2012). Temperature, salinity, $\mathrm{PH}$, dissolved oxygen and nutrient variations at five stations on the surface waters of Admiralty Bay, King George Island, Antarctica, during the summers from 2009 to 2012. Annual Activity Report INCT-APA, 96-100.

Hashihama, F., Hirawake, T., Kudoh, S., Kanda, J., \& Furuya, K. (2008). Size fraction and class composition of phytoplankton in the Antarctic marginal ice zone along the $140^{\circ}$ E meridian during February-March 2003. Polar Science, 2(2), 109-120. http://dx.doi.org/10.1016/j.polar.2008.05.001

Huot, Y., Babin, M., Bruyant, F., Grob, C., \& Twardowski, M. S. (2007). Does chlorophyll a provide the best index of phytoplankton biomass for primary productivity studies? Biogeosciences Discussions, 4(2), 707-745. http://dx.doi.org/10.5194/bgd-4707-2007

Kopczynska, E. E. (1980). Small-scale vertical distribution of phytoplankton in Ezcurra Inlet, Admiralty Bay, South Shetland Islands. Polish Polar Research, 1, 77-96.

Kopczynska, E. E. (2008). Phytoplankton variability in Admiralty Bay, King George Island, South Shetland Islands: six years of monitoring. Polish Polar Research, 29(2), 117-139. 
Lange, P. K., Tenenbaum, D. R., Braga, E. S. B., \& Campos, L. S. (2007). Microphytoplankton assemblages in shallow waters at Admiralty Bay (King George Island, Antarctica) during the summer 2002-2003. Polar Biology, 30(11), 1483-1492. http:// dx.doi.org/10.1007/s00300-007-0309-8

Lipski, M. (1987). Variations of physical conditions, nutrients and chlorophyll a contents in Admiralty Bay (King George Island, South Shetland Islands). Polish Polar Research, 8, 307-332.

Martin, J. H., Gordon, R. M., \& Fitzwater, S. E. (1991). The Case for iron. Limnology and Oceanography, 36(8), $1793-1802$. http://dx.doi.org/10.4319/lo.1991.36.8.1793

Mendes, C. B. R., Tavano, V. M., Leal, M. C., Souza, M. S., Brotas, V., \& Garcia, C. A. E. (2013). Shifts in the dominance between diatoms and cryptophytes during three late summers in the Bransfield Strait (Antarctic Peninsula). Polar Biology, 36(4), 537-547. http://dx.doi.org/10.1007/s00300-012-1282-4

Moline, M. A., \& Prézelin, B. B. (1996). Long-term monitoring and analyses of physical factors regulating variability in coastal Antarctic phytoplankton biomass, in situ productivity and taxonomic composition over subseasonal, seasonal and interannual time scales. Marine Ecology Progress Series, 145, 143-160. http://dx.doi.org/10.3354/meps145143

Moline, M. A., Claustre, H., Frazer, T. K., Schofield, O., \& Vernet, M. (2004). Alteration of the food web along the Antarctic Peninsula in response to a regional warming trend. Global Change Biology, 10(12), 1973-1980. http://dx.doi.org/10.1111/ j.1365-2486.2004.00825.x

Neveux, J., \& De Billy, G. (1986). Spectrofluorometric determination of chlorophylls and pheophytins. Their distribution in the western part of the Indian Ocean (July to August 1979). Deep-Sea Research, 33(1), 1-14. http://dx.doi.org/10.1016/01980149(86)90104-4

Neveux, J., \& Lantoine, F. (1993). Spectrofluorometric assay of chlorophylls and phaeopigments using the least squares approximation technique. Deep-Sea Research I, 40(9), 1747-1765. http://dx.doi.org/10.1016/0967-0637(93)90030-7

Neveux, J., Tenório M. M. B., Jacquet, S., Torréton, J. P., Douillet, P., Ouillon, S. et al. (2009). Chlorophylls and Phycoerythrins as Markers of Environmental Forcings Including Cyclone Erica effect (March 2003) on Phytoplankton in the Southwest Lagoon of New Caledonia and Oceanic Adjacent Area. International Journal of Oceanography, 2009, 1-19. Article ID 232513. http://dx.doi.org/10.1155/2009/232513

Rose, J. M., Feng, Y., DiTullio, G. R., Dunbar, R. B., Hare, C. E., Lee, P. A. et al. (2009). Synergistic effects of iron and temperature on Antarctic phytoplankton and microzooplankton assemblages. Biogeosciences, 6, 3131-3147. http://dx.doi.org/10.5194/ bg-6-3131-2009

Smith, C. R., Mincks, S., \& DeMaster, D. (2008). The FOODBANCS project: Introduction and sinking fluxes of organic carbon, chlorophyll-a and phytodetritus on the western Antarctic Peninsula continental shelf. Deep-Sea Research II, 55, $2404-2414$. http://dx.doi.org/10.1016/j.dsr2.2008.06.001

Tenenbaum, D. R., Barrera-Alba, J. J., Duarte, R. B., \& Tenório, M. M. B. (2011). Plankton structure a in shallow coastal zone at Admiralty Bay, King George Island, West Antarctic Peninsula (WAP): pico, nano and microplankton and chlorophyll biomass. Annual Activity Report 2011 INCT-APA, 108-114.

Tenório, M. M. B., Le Borgne R., Rodier M., \& Neveux J. (2005). The impact of terrigeneous inputs on the Bay of Ouinné (New Caledonia) phytoplankton communities: a spectrofluorometric and microscopic approach. Estuarine, Coastal and Shelf Science, 64, 531-545. http://dx.doi.org/10.1016/j.ecss.2005.02.030

Tenório, M. M. B., Duarte, R. B., Barrera-Alba, J. J., \& Tenenbaum, D. R. (2011). Plankton Structure in shallow coastal zone at Admiralty Bay, King George Island, West Antarctic Peninsula (WAP): chlorophyll biomass and size-fractionated chlorophyll during austral summer 2009/2010. Annual Activity Report 2010 INCT-APA, 115-120. 